\title{
Midline prostatic cyst in a young man with lower urinary tract symptoms
}

\author{
Barun Saha, Rajan Kumar Sinha, Subhabrata Mukherjee, Nilanjan Mitra
}

Department of Urology, $\mathrm{CNMCH}$, Kolkata, West Bengal, India

Correspondence to Dr Rajan Kumar Sinha, rajan_rims@yahoo.co.in

Accepted 7 December 2014

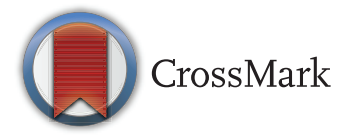

To cite: Saha B, Sinha RK Mukherjee $\mathrm{S}$, et al. BMJ Case Rep Published online: [please include Day Month Year] doi:10.1136/bcr-2014207816

\section{DESCRIPTION}

A 35-year-old man presented with a 1-year history of increased urinary frequency, poor urinary flow, incomplete voiding sensation and dysuria. He was subjected to repeated urine culture and antibiotics, but his symptoms persisted. Digital rectal examination revealed a grade II smooth firm prostate. A sonogram showed a thickened bladder wall and post-void residual (PVR) of $112 \mathrm{~mL}$ with a midline prostatic cyst. A retrograde urethrogram revealed a midline prostatic cyst communicating with the urethra (figure 1). Maximum flow rate was $11.6 \mathrm{~mL} /$ s. The patient underwent transrectal ultrasoundguided aspiration, but the cyst recurred. Subsequently, transurethral deroofing was performed. One month later the patient had a remarkable improvement of lower urinary tract symptoms (LUTS). Maximum flow had improved to $20.2 \mathrm{~mL} / \mathrm{s}$ and PVR had dropped to $32 \mathrm{~mL}$. At 1 year follow-up the patient was asymptomatic with maximum flow rate $20 \mathrm{~mL} / \mathrm{s}$ and PVR was insignificant.

A congenital midline prostatic cyst is not an uncommon finding, with $1 \%$ incidence in autopsy

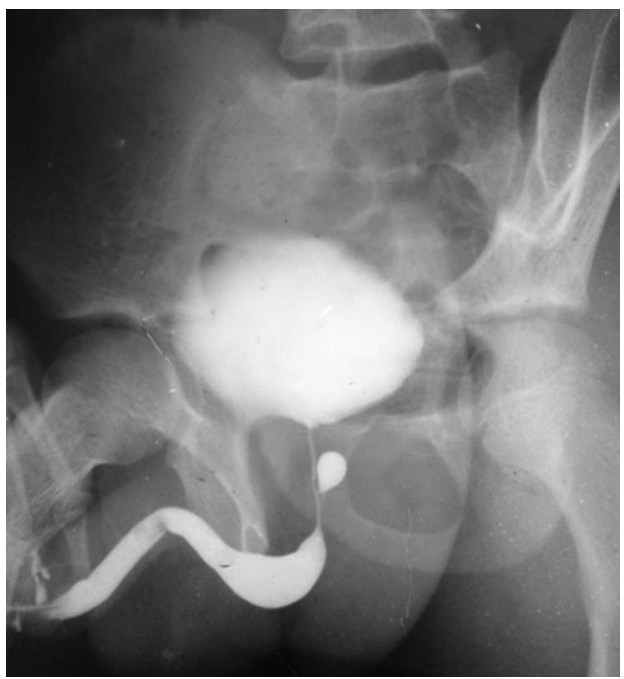

Figure 1 Retrograde urethrogram revealing a midline prostatic cyst communicating with the urethra. findings and $7-8 \%$ in ultrasound screening programmes. ${ }^{1}$ But a prostatic cyst with symptomatic LUTS in a young patient is rare. These cysts can be classified according to their location and relation with surrounding structures. Furuya $e t a l^{2}$ have classified prostatic cysts as type 1 (noncommunicating with urethra), type $2 \mathrm{a}$ (communicating with urethra-most common), type $2 \mathrm{~b}$ (communicating with urethra and seminal vesicle) and type 3 (cystic dilatation of ejaculatory duct) based on contrast studies. Our case is type 2a according to the above classification.

Prostatic cysts are generally asymptomatic and do not require treatment. Symptomatic cases can be managed by transrectal aspiration, transurethral incision, deroofing or marsupialisation. ${ }^{3}$

\section{Learning points}

A midline prostatic cyst as a cause of lower urinary tract symptoms in a young patient is an uncommon finding.

- Prostatic cysts can be classified in various ways, but radiological imaging-based classification is the easiest way.

- Only symptomatic cases require treatment.

Contributors BS, SM and NM were involved in manuscript design and editing. RKS was involved in data collection, manuscript design and final editing.

Competing interests None.

Patient consent Obtained.

Provenance and peer review Not commissioned; externally peer reviewed.

\section{REFERENCES}

1 Ishikawa M, Okabe H, Oya T, et al. Midline prostatic cysts in healthy men: incidence and transabdominal sonographic findings. Am J Roentgenol 2003;181:1669-72.

2 Furuya $\mathrm{R}$, Furuya $\mathrm{S}$, Kato $\mathrm{H}$, et al. New classification of midline cysts of the prostate in adults via a transrectal ultrasonography-guided opacfication and dye-injection study. BJU Int 2008;102:475-8.

3 Sheu JY, Yin JH, Tung CM. Midline prostatic cyst in a young man with difficult voiding. Incont Pelvic Floor Dysfunct 2012;6:112-14. 
Copyright 2014 BMJ Publishing Group. All rights reserved. For permission to reuse any of this content visit http://group.bmj.com/group/rights-licensing/permissions.

BMJ Case Report Fellows may re-use this article for personal use and teaching without any further permission.

Become a Fellow of BMJ Case Reports today and you can:

- Submit as many cases as you like

- Enjoy fast sympathetic peer review and rapid publication of accepted articles

- Access all the published articles

- Re-use any of the published material for personal use and teaching without further permission

For information on Institutional Fellowships contact consortiasales@bmjgroup.com

Visit casereports.bmj.com for more articles like this and to become a Fellow 